16 a 18 de outubro de 2019 - Campinas | Brasil

\title{
Do corpo miraculado aos exames: os objetos médicos na verificação de milagres da Igreja Católica
}

\author{
Lucas Toledo M. Baccetto*, Rodrigo Toniol
}

\begin{abstract}
Resumo
Esta pesquisa teve como objetivo principal analisar a atuação de médicos, na função de peritos, nos processos de beatificação e canonização dos candidatos à santidade na Igreja Católica. Tratou-se do desdobramento da investigação anterior cujo enfoque analítico se concentrou em um aspecto mais global do fenômeno. Percebemos, na bibliografia da área, certas pistas a respeito dos objetos que caracterizariam a prova de um caso de cura possivelmente milagrosa nessa etapa de avaliação médica nos processos investigativos. O material em questão diz respeito às provas normalmente vinculadas ao processo realizado pela Igreja Católica: testemunhos, exames de radiografia, relatórios e prontuários médicos, tomografias computadorizadas, anamneses, entre outros exames médicos. Propusemos para essa pesquisa um deslocamento metodológico, centrando os processos que envolvem nosso objeto analítico através da perspectiva que privilegia a materialidade dos objetos. Com isso, analisamos o papel desses objetos na composição da etapa eclesiástica, nos debruçando tanto sobre os testemunhos médicos, quanto sobre a característica geral dos objetos anexados na qualidade de provas.
\end{abstract}

\section{Palavras-chave: \\ Milagres; Ciências Médicas; Antropologia das Materialidades.}

\section{Introdução}

A atuação de médicos nos processos de verificação de milagres da Igreja Católica ocorre na etapa que tem por objetivo apurar as condições clínicas de uma cura física considerada como possivelmente milagrosa. Sua participação se dá como testemunhas oculares do evento miraculoso ou na condição de peritos. Quando atuam como testemunhas, os médicos devem fornecer relatos, exames e outros objetos que ajudam na reconstituição do caso. Já na sua atuação como peritos, ela ocorre nas duas fases processuais. Na fase diocesana, os médicos convocados normalmente são da região onde o evento ocorreu, e eles participam realizando exames e uma consulta clínica para se avaliar o atual estado de saúde da pessoa curada. Já na fase romana, médicos italianos são convocados pelo Vaticano para produzirem laudos médico-legais avaliando as provas recolhidas e/ou participarem como componentes da Consulta Medica, momento no qual devem avaliar quatro dimensões que atestam uma possível miraculosidade do evento: a rapidez, eficácia, durabilidade e inexplicabilidade científica. Assim, para que uma cura possa avançar no processo e ser avaliada em sua dimensão teológica, ela deve ser considerada rápida / instantânea, completa, duradoura e inexplicável cientificamente.

\section{Resultados e Discussão}

Esta investigação foi realizada a partir da análise documental do Processus da canonização de Gianna Beretta Molla (compilação documentação da fase diocesana), e da Positio Super Miraculo da canonização de Madre Paulina (documento final da investigação). Notamos nos testemunhos dos médicos do caso de Gianna que, ainda que a Igreja estruture o interrogatório a partir de uma separação entre as dimensões religiosa e médica do caso, os depoimentos das testemunhas operam sempre no imbricamento das duas dimensões. Mais do que isso, as controvérsias médicas suscitadas nos depoimentos se ligam a um debate que ocorre em todo o processo investigativo: o estabelecimento das fronteiras entre o natural e o sobrenatural, e o papel da medicina em analisar a ordem natural. Já no caso de Paulina, no qual os peritos italianos acusam a falta de documentação sobre o caso, o que chama a atenção é a dependência que esses peritos têm a respeito da documentação oferecida a eles. Enquanto os peritos locais do caso de Paulina tinham à sua disposição o corpo da suposta miraculada para a realização de exames clínicos, os peritos italianos tiveram de basear seu julgamento unicamente a partir dos objetos dispostos como provas: era preciso que, de alguma forma, esse corpo se colocasse à disposição de seus olhares.

\section{Conclusão}

Concluímos que a posição da Igreja Católica sobre o que seria um milagre (intervenção sobrenatural na natureza) se encontra em disputa nos testemunhos. Isso se dá pela recusa de alguns médicos em avaliarem somente a ordem natural. Ao mesmo tempo, a transladação do corpo miraculado na investigação ocorre através dos objetos que inscrevem o corpo miraculado: os exames e as conclusões médicas. Assim, uma série de dispositivos inscritores $^{1}$ são articulados pelos atores locais para que esse corpo possa dar lugar a esses objetos, que por sua vez são enviados ao Vaticano e passam a possibilitar que os peritos de lá avaliem o caso. Trata-se de se pensar o corpo miraculado como um móvel imutáve ${ }^{2}$, um objeto que pode ser transportado de um lado para outro sem que se transforme ao longo do processo.

\section{Agradecimentos}

Agradeço ao Serviço de Apoio ao Estudante/SAE UNICAMP pelo financiamento desta pesquisa, e ao Prof. Dr. Rodrigo Toniol pela cuidadosa orientação.

\footnotetext{
${ }^{1}$ Latour, Bruno. Woolgar, Steve. A vida de laboratório. Rio de Janeiro: Relume-Dumará, 1997.

2 Latour, Bruno. Cognição e visualização: pensando com olhos e mãos. In: Terra Brasilis (Nova Série), v.4, 2015.
} 